Kansas State University Libraries

New Prairie Press

\title{
Rooted in the Soil: The Social Experiences of Black Graduate Students at a Southern Research University
}

Juanita Johnson-Bailey

Thomas Valentine

Ronald M. Cervero

The University of Georgia

Tuere A. Bowle

North Carolina State

See next page for additional authors

Follow this and additional works at: https://newprairiepress.org/aerc

Part of the Adult and Continuing Education Administration Commons

(c) (1) (9)

This work is licensed under a Creative Commons Attribution-Noncommercial 4.0 License

\section{Recommended Citation}

Johnson-Bailey, Juanita; Valentine, Thomas; Cervero, Ronald M.; and Bowle, Tuere A. (2006). "Rooted in the Soil: The Social Experiences of Black Graduate Students at a Southern Research University," Adult Education Research Conference. https://newprairiepress.org/aerc/2006/papers/34

This is brought to you for free and open access by the Conferences at New Prairie Press. It has been accepted for inclusion in Adult Education Research Conference by an authorized administrator of New Prairie Press. For more information, please contact cads@k-state.edu. 


\section{Author Information}

Juanita Johnson-Bailey, Thomas Valentine, Ronald M. Cervero, and Tuere A. Bowle 


\title{
Rooted in the Soil: The Social Experiences of Black Graduate Students at a Southern Research University
}

\author{
Juanita Johnson-Bailey, Thomas Valentine, Ronald M. Cervero \\ The University of Georgia \\ Tuere A. Bowles \\ North Carolina State
}

Keywords: Black graduate students, retention, graduate students

\begin{abstract}
The experiences of Black graduate alumni, 1962-2003, at a major Southern Research University were examined in a comprehensive survey. The areas explored were: relationships with faculty, students, and the institution.
\end{abstract}

The experiences of Black graduate alumni, 1962-2003, at a major Southern Research I University were examined in a comprehensive quantitative study. The areas explored were: relationships with faculty, students, and the institution. This study was conducted in an effort to explore the experiences of Blacks and to provide an accurate and first hand account of the Black graduate student experiences. The research questions guiding this study were: To what extent did Black graduate students experience social support during their studies? What types of social problems did Black graduate students experience during their studies? The data reported in herein only addresses the research question on social experiences. The study revealed that the social experiences of Black graduate students are different from those of White graduate students.

\section{Review of the Literature}

In the higher education environs of Research Universities, Blacks remain underrepresented as students, faculty, and administrators - still invisible women and men against the backdrop of an America educational system where education is a primary route to upward mobility and increased wages (Adair, 2001). Considering that graduate degrees are the new required standard for acceptance into careers that secure one's middle class status, graduate education has even more significance for Black Americans whose economic status lags behind that of White Americans (Adair, 2001; Bowen \& Bok, 1998; Gurin, Dey, Hurtado, \& Gurin, 2002; Yasso, Parker, Solórzano, \& Lynn, 2004).

There are nine themes that are commonly associated with Black college students on historically White campuses: a) isolation and loneliness; b) racial hostility; c) persistence; d) psychological distress e) stereotyping; f) surplus invisibility ; g) invisibility) ; h) bias in grading; and i) indifference/insensitivity. Using these themes, the research team enlisted Black graduate student volunteers at the Southern Research University under study from across academic disciplines to develop and validate a survey instrument. The study's sample and methodology are characteristics that separate this research study from other studies in the literature that rely solely on survey data. 


\section{Conceptual Frame and Methods}

The conceptual framework is based on critical race theory (Bell, 1992; DuBois, 1953; Hooks, 1989; Outlaw, 1983). Therefore the resulting frame focused on interpreting the data with an awareness of the diffusive nature of power and postionality (Foucault, 1980). Influenced by this theoretical base, the researchers approached the study and the resulting data with an acknowledgment of the systems of oppression that had produced and structured the inequalities in the educational system.

This study employed a mailed, self-completion questionnaire. In its final form, the questionnaire has five sections. The first two sections measure the perceived social support graduate students received from four groups: Black professors, White professors, Black students, and White students. The third section asks about a broad range of race-related social problems. The fourth section consists of a series of open-ended questions which afforded respondents the opportunity to describe their experiences in their own words. The fifth section requested demographic information.

The study sample consisted of the population of Black, graduate alumni since the desegregation of the university. Data collection consisted of the distribution of the questionnaire in three consecutive mailings at approximately three week intervals. Of the 678 returns received, 92 were considered invalid for one of the following reasons: (a) they had not received a graduate degree, (b) they did not indicate the degree they received, (c) they were not Black, or (d) they left substantial sections of the questionnaire blank. The response rate was $30.6 \%$.

Analysis of the data sets for the quantitative and the qualitative data sets were conducted independently of each other and by different research team members. The selected-response items (Questions 1 through 58 and 65 through 72) were assigned numerical codes, and data were entered into an SPSS data set. These items were then analyzed using a variety of univariate, bivariate, and multivariate statistical analyses as required by the research questions. The openended questions (Questions 59 through 64) were typed into MS-Word documents and subjected to qualitative content analysis (Krippendorf, 2004; Weber, 1990). This analysis allowed us to identify topics and themes that were generated from the graduates in their own words rather than in the restricted language of selected-response questions. The data was managed using NVivo (computer assisted qualitative data analysis software)

A team of five research assistants typed the responses to the six open-ended questions: a) what was the single biggest factor that helped you, as a Black graduate student, complete your graduate degree; b) what was the greatest challenge you faced during your graduate studies; c) did you experience racism on campus; d) in general, how well were you treated by University personnel other than professors (e.g., service workers, secretaries, librarians, maintenance personnel, campus police, etc.); e) what would have made your experience better; and 6) what else do you want to tell us about your experiences as a graduate student? The data collection was supervised by a team manager who performed a verification process between the written and typed data.

\section{Findings}

In response to the research question, regarding what type of social problems Black graduate students experienced during their tenure at the University, the most frequent types of responses could be coded under the category of discriminatory and racially hostile acts. What stood apart in this category can best be described as the passive and quietly hostile environment 
described by the students. The participants expressed that they experienced an unwelcoming environment in which they felt like intruders who knew they were merely tolerated.

Quantitative Findings Related to Social Experiences

This research question called for the search for latent dimensions of the social problems encountered by Black graduate students. A large number of items indicative of social problems were measured and the data were subjected to exploratory factor analysis. Many solutions were examined in an attempt to achieve conceptual clarity. Ultimately, we settled on a five factor solution using orthogonal rotation and a loading criterion of .55. The factors, which are delineated in Tables 5 through 9, can be described as follows:

1. White professor discrimination is defined by items indicative of overt or subtle racism on the part of White faculty members. Although the actions described vary with respect to severity, all represent a breech in the trust and respect that characterize instructor-student relations during graduate education at its best.

2. Enforced social isolation is defined by items describing social neglect and avoidance on the part of White students. Through such behaviors, many Black graduate students were systematically denied the rich social experiences and informal learning opportunities that one might expect to find a major university.

3. Underestimation of academic ability is defined by items that describe racist assumptions about academic limitations of Black graduate students by both White faculty members and White students. Few white scholars can imagine the psychological and motivation impact of having people assume you are academically deficient until you prove them wrong.

4. White student discrimination is defined by items indicative of overt or subtle racism on the part of White students. The actions described represent range from the rude to the confrontational. All can be construed as threatening when one considers the huge disparity between the relative numbers of White and Black graduate students.

5. Forced representation for the race is defined by only two highly correlated items. The items describe the tendency of White professors and students to ask Black students to "speak for the race." Although sometimes undertaken in a misguided spirit of respect—giving voice to one of the few Black people in a sea of White faces - this absurd practice is indicative of a deepseated racism that assumes that Black people are a simple, monolithic group that lacks the variety of other racial groups.

Taken together, these five "factors of social problems" represent, in plainer English, the "dimensions of racism" which our graduate students experience. Factor analysis is useful for discovering such dimensions; however, the tables above give no indication about the relative impact of these five dimensions on the lives of Black graduate students, since factor loadings are an indicator of the "conceptual integrity" (based on covariation) rather than magnitude. Table 10 presents figures related to magnitude or relative severity, in the form of mean item means for each of the factors.

The most severe problem confronting Black graduate students pertains to stereotyping, in the form of underestimation of ability and the treatment of blacks as a monolithic racial group. Next in severity are the dimensions that pertain primarily to interactions with White students, who are force social isolation on Black graduate students and treat them with obvious discrimination. The least severe dimension, which still evidences a mean that approaches the response scale midpoint, is discrimination by White Professors.

For respondents who graduated before 1986 and those who graduated 1996 or later. Independent sample t-tests found significant change on three Dimensions: a) White Professor 
Discrimination has decreased over time; b) underestimation of Academic Ability has decreased over time; and c) White Student Discrimination has increased over time. There have been no changes on two Dimensions: Enforced social isolation has stayed the same and forced Representation for the Race has stayed the same.

Qualitative Findings Related to Social Experiences

In response to the second research question, regarding what type of social problems Black graduate students experienced during their tenure at the University, the most frequent types of responses could be coded under the category of discriminatory and racially hostile acts. What stood apart in this category can best be described as the passive and quietly hostile environment described by the students. The participants expressed that they experienced an unwelcoming environment in which they felt like intruders who knew they were merely tolerated.

The research question regarding social problems was significantly influenced in direct response to survey question 61, "Did you experience racism on the University campus?" Of the 678 respondents, 384 of the former students answered affirmatively and 170 answered negatively. Therefore, over half of the respondents completing the survey experienced racism at the University. The remaining 24 of the 678 surveys returned yielded answers that were coded as neutral or not applicable. Interestingly, the survey group wrote more on this open-ended question regarding racism than on other open-ended questions. Stories emerged in response to this question that can be classified accordingly: a) police harassment; b) racial epithets, c) isolation in the classroom; and d) an unwelcoming environment at extra curricula activities. If this can be seen as an indication of responses, it is not unreasonable, to conjecture that the over nonresponding 1,000 + participants might have been discouraged from responding by their experiences here at the University or their possible lack of commitment to further participation in matters concerning the University. Again, it must be emphasized that the participants responding to this survey were Black graduate students who successfully matriculated at the major Research I University.

\section{Discussion}

The quantitative data from the survey questions and the qualitative data from the six open-ended questions yielded consistently similar responses. Moreover, the research team posits that the data exist in tandem, each supporting, expanding, and clarifying the other. For example, the former students speak across the decades as to discrimination on the part of both students and professor. However, only the quantitative analysis can show that White professor discrimination has decreased while White student discrimination has increased. And consequently, only the qualitative data can display the sense of what the participants meant by discrimination.

The survey data indicated that White professor discrimination had decreased over the years, while White student discrimination has increased. It is posited by the research team that the varied circumstances of the White students and the White professors may be contribute significantly to this difference. First, the population of White faculty is more consistent than the population of White students that is constantly changing due to student turnover: graduation, dropout, and transfer. Therefore the stable White professor group would have more exposure to Black students than would the White student group. This phenomena of how exposure might impact or affect White professor discrimination is also based in part on the students limited exposure to a diverse study body prior to their graduate school experience (Engberg, 2004; Gurin, Dey, Hurtado, \& Gurin, 2002). A second point that is set forth is that the population of 
students at state flagship universities is drawn primarily from the state's citizenry. Whereas the base for faculty is drawn more widely, including a diverse national and international representation. A third consideration is that White professors have more power in the classroom setting than White students and can therefore use their perspective of privilege to be more accommodating in their view of Black students.

In general Black students at historically White institutions express a disconnection from their institutions and their programs; however, this disconnection is of more consequence for graduate students because the literature shows that there is a direct correlation between a graduate student's connection to their program and their ability to finish their graduate studies (Astin, 1982; Chavous, Rivas, Green \& Helaire, 2002; Ellis, 2001; Feagin, 1992; Gasman, Gerstl-Pepin, Anderson-Thompkins, Rasheed, \& Hathaway, 2004; Golde, 2005; Margolis, 1998; Onwuegbuzie, 1999). Therefore, a Black graduate student who is disconnected from their program is more likely not to graduate.

The interconnectedness of the social experiences and the students' ability to succeed and persist is part of the graduate student circumstance that is not considered as within the realm of the University's concern. However, as revealed by this study, the professors, students, and university personnel all affect the social experiences of Black graduate students in this study. Therefore, unless the University and more importantly graduate programs, begin to consider and intentionally make an effort to positively impact the social experiences of its Black graduate students, their experiences will continue relatively unchanged.

While it can be argued that the collective experiences from these participants are representative of only a Southern Research University, it is more logical to assume that these circumstances are perhaps representative of the broader graduate experience. The researchers set forth this position since the data collected in previous studies, which represented the wide American undergraduate collegiate, were also consistently applicable to the data from the graduate participants in this Southern sample.

This study holds relevance for administrators at major universities and indicates that there is a need for development of an understanding and acceptance of the fact that the experiences of Black graduate students at the University are qualitatively and quantitatively different from those of other students. This study also indicates that it can not be argued or rationalized that the participants' perceptions might be affected by the school's legacy of segregation or impacted by other students (over which the university has little control).

\section{References}

Adair, V. (2001). Poverty and the (broken) promise of higher education. Harvard Educational Review, 71(2), 217 239.

Astin, A. (1982). Minorities in higher education. San Francisco: Jossey-Bass.

Bowen, W.G., \& Bok, D. (1998). The shape of the river: Long-term consequences of considering race in college and university admissions. Princeton: Princeton University Press.

Chavous, T.D., Green, L., \& Helaire, L. (2002), Role of student background, perceptions of ethnic fit, and racial identification in the academic adjustment of African American students at a predominantly white university. Journal of Black Psychology, 28(3), 234-260.

DuBois, W. (1903/1953). The souls of black folk. Greenwich, CT: Fawcett Publications.

Ellis, E.M. (2001). The impact of race and gender on graduate school socialization, satisfaction with doctoral study, and commitment to degree completion. The Western Journal of Black Studies, 25(1), 30-45.

Engberg, M. (2004). Improving intergroup relations in higher education: A critical examination of the influence of educational interventions on racial bias. Review of Educational Research, 74(4), 473-524.

Feagin, J.R. (1992). The continuing significance of racism: Discrimination against Black students in White colleges. Journal of Black Studies, 22(4), 546-578. 
Foucault, M. (1980). Power/knowledge. New York: Pantheon.

Gasman, M., Gerstl-Pepin, C., Anderson-Thompkins, S., Rasheed, L., \& Hathaway, K. (2004). Negotiating power, developing trust: Transgressing race and status in the academy. Teachers College Record, 106(4), 689-715.

Golde, C.M. (2005). The role of department and discipline in doctoral student attrition: Lessons from four departments. Journal of Higher Education, 76(6), 669-699.

Gurin, P., Dey, E., Hurtado, S., \& Gurin, G. (2002). Diversity and higher education: Theory and impact on educational outcomes. Harvard Educational Review, 72(3), 330-366.

Hooks, B. (1989). Talking back: Thinking feminist, thinking black. Boston: South End.

Krippendorf, K. (2002). Content analysis: An introduction to its methodology ( $2^{\text {nd }}$ ed.). Thousand Oaks, CA: Sage.

Margolis, E. \& Romero, M. (1998). "The department is very male, very White, very old, and very conservative":

The functioning of the hidden curriculum in graduate sociology departments. Harvard Educational Review, $68(1), 1-32$.

Onwuegbuzie, A. J. (1999). Statistics anxiety among African American graduate students: An effective filter? Journal of Black Psychology, 25(2), 189-209.

Outlaw, L. T., Jr. (1983). Race and class in the theory and practice of emancipatory social transformation. In L. Harris (Ed.), Philosophy born of struggle: Anthology of African-American philosophy from 1917 (pp. 117129). Dubuque, IA: Kendall/Hunt.

Solorzano, D. (2000). Critical race theory, racial microaggressions, and campus racial climate: The experiences of African American college students. Journal of Negro Education, 69(1-2), 60-73

Weber, R. P. (1990). Basic content analysis ( $2^{\text {nd }}$ ed.). Newbury Park, CA: Sage.

Yasso, T.J., Parker, L., Solorzano, D.G., \& Lynn, M. (2004). From Jim Crow to Affirmative Action and back again: A critical race discussion on racialized rationales and access to higher education. Review of Research in Education, 28, 1-25. 